\title{
Foreign Direct Investment: A Journey To Economic Growth In Ghana - Empirical Evidence
}

George Owusu-Antwi, Ghana Institute of Management and Public Administration, Ghana James Antwi, Ghana Institute of Management and Public Administration, Ghana Peter K. Poku, Ghana Institute of Management and Public Administration, Ghana

\begin{abstract}
Foreign Direct Investment (FDI) has been viewed as a major stimulus to economic growth in developing countries. Its ability to deal with two major obstacles; namely, shortages of financial resources and technology and skills, has made it the center of attention for policymakers in lowincome countries in particular. In spite of the significance generated by FDI flows, the flow to developing countries and the world, in general, has witnessed persistent decline over the years. The implication for the drop means that competition to attract FDI has increased as developing countries continue to create the enabling environment to attract foreign investors. Ghana, in particular, has, over the last decade, pursued various forms of economic reforms and liberalization of trade regimes in order to become more competitive in the international financial market. A handful of papers has recently dealt with FDI flows in Ghana. However, most of these studies are concerned with strategic FDI policy to attract FDI flows.
\end{abstract}

The purpose of this study is to empirically determine the factors that influence FDI flows in Ghana, using time series data from 1988 to 2011. Regression analysis was carried out using relevant econometric techniques. The results of the study capture trade openness, exchange rate, natural resources, and infrastructure as the drivers of FDI in Ghana. Macroeconomic variables, such as inflation and per capita gross domestic products, were also registered to impact the determinants of FDI flows in Ghana. The contribution of this paper is that economic liberalization was found to be significant, indicating that policymakers' efforts in liberalizing the economic activities may necessarily translate into significant FDI inflows into the country.

Keywords: Foreign Direct Investment; Liberalization; Macroeconomic; Exchange Rate; Policymakers

\section{INTRODUCTION}

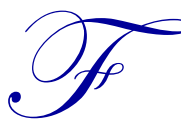

oreign Direct Investment (FDI) has been viewed as a major stimulus to economic growth in developing countries. Its ability to deal with two major obstacles; namely, shortages of financial resources and technology and skills, has made it the center of attention for policymakers in lowincome countries in particular. It can impact the host economy through a variety of channels. Principally, it helps by adding to the resources available for investment and capital formation. The transfer of technology, skills, innovative capacity, and organizational and managerial practices between countries is also enhanced through the activities of foreign direct investors. Indeed, foreign direct investment inflows remain an important barometer that guides the direction and orientation of the development and implementation of economic policies and strategies of governments in these regions. It is also common knowledge that foreign direct investment inflows provide badly needed capital to finance domestic activities creating the platform for the transfer of technology and technical knowhow for the host country. There is no doubt that these factors are indispensable prerequisites that can lay the foundation for the integration of developing economies into the global economy as part of the overall drive towards economic development. Researchers have focused on measuring these effects and finding ways to maximize the beneficial aspects. 
In spite of the significance generated by FDI flows, the flows to developing countries, and the world in general, has witnessed persistent decline over the years. FDI flows into Africa declined to about \$11 billion in 2002 after a surge to $\$ 19$ billion in 2001. In view of this downturn, the region's share of global FDI flows fell from 2.3\% to $1.7 \%$ (UNCTD, 2003). The implication for the drop means that competition to attract FDI has increased as developing countries continue to create the enabling environment to attract foreign investors. Ghana, in particular, has, over the last decade, pursued various forms of economic reforms and liberalization of trade regimes in order to become more competitive in the international financial market. In Ghana, there has been a much more liberalized regime for FDI, addressing investor concerns, privatizing public enterprises and actively promoting investment, all of which are aimed at creating a good environment to boost investor confidence. Again, the government of Ghana has expanded the scope for FDI by reducing the number of industries closed to foreign investors. Given the growing importance of FDI in Ghana, it has been an area that has not been empirically research; therefore it is vital to explore the determinant of FDI flows. A handful of papers has recently dealt with FDI flows in Ghana. Among others are Aseidu (2006, 2001) and Morrisset (2000). However, most of these studies are concerned with strategic FDI policy to attract FDI flows.

\section{ECONOMIC OUTLOOK}

Ghana has continued to consolidate democratic rule and now enjoys a more open society with a vibrant media and strong public dialogue. As a result of these and other political achievements, Ghana outperforms most countries in West Africa and in the continent on measures of civil liberty, political rights and political stability (African Development Fund, 2012). Ghana has a population of about 25 million and the second largest economy in the sub-Saharan region. Over the past decade, Ghana has reflected a slow structural transformation, the service sector which comprises of non-tradable services contribute the largest share of the GDP, followed by agriculture and industry. Ghana also relies heavily on commodities, such as cocoa, gold, and, more recently, oil, as a source of external revenue. Currently, Ghana is considered as the most promising economies in West Africa and the African continent as a whole. The economy of Ghana picked up in 2010 and grew in real terms by $7.7 \%$ after a slowdown of economic activities in 2009. GDP in the year 2011 increased by $13.7 \%$ (7.5\% excluding oil). This was attributed to oil revenues and strong export performance of cocoa and gold in volume and prices (African Department Fund, 2012). With successive declining inflation and the fiscal deficit, Ghana has tremendously improved its macroeconomic management. The sky is not cloudless despite these encouraging trends. Thus, on the fiscal front, there is the need to clear the expenditure arrears and improve domestic resource mobilization efforts. However, Ghana's external dynamics remain subject to moderate risk of debt distress; to this effect, there is a need to guard against the excessive debt accumulation, especially in context where the public debt stock sharply rose to $39.0 \%$ of the GDP in 2011 (African Department Fund, 2012). In light of this, the government has sought help from the IMF and the World Bank to provide assistance for debt management issues and the government has committed to use debt financing for projects that can generate revenue to repay the debt service. Ghana has demonstrated its commitment to strengthen governance. It has maintained or improved its rating on most governance indicators; especially in participation of human rights, public management and human development. Steps have also been taken to improve transparency and accountability. In Ghana, the private sector is being dominated by the informal sector with approximately $90 \%$ of the companies being MSMEs. The private sector is the main employer and the primary generator of exports. Its contribution to real GDP is estimated at about $22 \%$. The government has been actively improving the country's business environment. Despite the government support to the business environment, the private sector still faces issues that have confronted the development of the private sector. These include infrastructural weaknesses, cumbersome public administration structures, underdeveloped financial systems' low access to technology, and weak human capital. Ghana is an active member of key regional integration arrangements in West Africa and in the continent, including the African Union, the Economic Community of West African States, and the West African Monetary Zone1. It also maintains good relations with its traditional trading partners and donors, especially the US and UK, both of which have a large Ghanaian Diasporas (African Development Fund, 2012).

The outlook of Ghana remains generally favorable. According to African Development Fund (2012), macroeconomic conditions will continue to be positive despite the expected slowdown in commodity price increases. This slowdown will lead to a reduction of real GDP from $13.7 \%$ in 2011 to $8.3 \%$ at the end of 2012. The fiscal deficit, however, is expected to be maintained at prudently financed levels, even as the Government 
implements plans to fill the large infrastructure gaps that are consistent with the GSGDA. Current trends indicate that the government of Ghana $(\mathrm{GoG})$ is intending to diversify the economy so that the oil sector will not become the only driver of the economy. Sustainability includes green growth which will be lined with the country's economic ambitions.

\section{FDI FRAMEWORK}

Most of the studies that deal with FDI flows place more emphasis on specific factors that are geared toward multinational firms, specifically those that are related to competition among the firms themselves and with local firms. Theoretical studies on the determinants to FDI flows can be traced back to Adam Smith, Stuart Mill and Torrens; however, it was Ohlin (1933) who first addressed the issue of FDI determinants. According to Ohlin (1933), foreign direct investment can be included, mainly by the possibility of high profitability in the growing market, along with the possibility of financing these investments at relatively low rates of interest in the host country. Hymer (1960) ushers in a tradition in the study of multinational firms (MNFs). He stated that if MNFs are able to compete with local firms that have a much better knowledge of the local market and the environment, it is because MNFs present some sort of compensatory advantages, such as product differentiation and access to patented or proprietary information. With these advantages, MNF would prefer to supply the foreign market by way of direct investments (in developing countries) instead of through (direct) exports. Kindleberger (1969) slightly modifies Hymer's analysis. Instead of MNF behavior determining the market structure, it is the monopolistic competitive market structure that will determine the conduct of the firm, by internalizing its production. Similar analysis in which market structure dictates conduct was developed by Caves (1971). Caves (1971), also develops a similar analysis in which structure dictates conduct. FDIs will be made basically in sectors that are dominated by oligopolies. If there is product differentiation, horizontal investments may take place; i.e., in the same sector. If there is no product differentiation, vertical investments will be made in sectors that are behind in the productive chain of firms. The existence of FDI is further related to trade barriers as a way of avoiding uncertainties in supplies or as a way of imposing barriers to new firms on the external markets.

A second line of studies of the determinants of FDI is based on the idea of transaction cost internationalization. Buckley and Casson (1976) and (1981) and Buckley (1985) were the first to develop this hypothesis, starting with the idea that the intermediate product markets are imperfect, having higher transaction costs when managed by different firms. The internationalization theory emphasizes the intermediary product market and the formation of international production networks. The theory's main strength may lie in its capacity to address the dilemma between the licensing of production to a foreign agent and its own production. Within a framework that could be classified as microeconomics, there is the work of John Dunning. His analysis begins by stating that ownership of dissimilar assets may be considered as one of the factors responsible for the existence of multinational firms. Dunning develops an approach that must be understood, in his view as a paradigm (in the sense that it brings together conflicting theories, with no single outcome) known as OLI (ownership, location, internationalization).

According to Dunning's (1988) 'electric theory,' foreign direct investment (FDI) is determined by three sets of advantages of direct investment over the other institutional mechanisms available for a firm in satisfying the needs of its customers at home and abroad. The first is the ownership which includes the advantage that the firm has over its rivals in terms of its brand name, patent, and marketing. The second is the internationalization advantage; that is why a 'bundled' FDI approach is preferred to 'unbundled' product licensing, capital lending, or technical assistance (Wheeler and Mody, 1992). The third is the location-specific advantages, which relate to the importance for the firm to operate and invest in the host country and are those advantages that make the chosen foreign country a more attractive site for FDI than others.

Another line of thinking is represented by the product cycle model proposed by Vernon (1996). According to this model, since the innovations are labor savers, they (quasi) initially appear in those countries that are more capital intensive, especially the US (the model was developed in the mid-60s). Gradually, production has relocated to countries that are less capital intensive and, lastly, to developing countries. At the same time, production in richer countries is reoriented toward new products that incorporate innovations in products and processes. 


\section{LITERATURE REVIEW}

The effect of exchange rates on FDI has been examined with respect to changes in the bilateral level of the exchange rate between countries and also in the volatility of exchange rates (Blonigen, 2005). Froot and Stein (1991) present an imperfect capital markets story for why a currency appreciation may actually increase foreign investment by a firm. Imperfect capital markets mean that the internal cost of capital is lower than borrowing from external sources. Thus, an appreciation of the currency leads to increased firms in the foreign country that experiences the devaluation of their currency. Froot and Stein (1991) provide empirical evidence of increased inward FDI with currency depreciation through simple regressions using a small number of annual US aggregate FDI observations which Stevens (1997) findings are quite fragile to specification. Klein and Rosengren (1994), however, confirm that exchange rate depreciation increases USFDI using various samples of USFDI disaggregated by country source and type of FDI. Blonigen (2005) implicitly assumes that exchange rate effects on FDI are symmetric and proportional to the size of the exchange rate movement. Using a dynamic panel data of 26 transition economies between 1990 and 1999, Garibaldi et al (2001) analyzed a large set of variables which were divided into macroeconomic factors, structural reforms, institutional and legal frameworks. Their results show a significant relation between macroeconomic variables, such as inflation and exchange rate regime. Loree and Guisinger (1995) studied the determinants of foreign direct investment by the United States between 19977 and 1982. Their results show infrastructure to be the most significant factor in determining FDI flows. They concluded that variables related to the host country policy were significant only when infrastructure was an important determinant factor. Generally, the larger the market size of the host country, the more attractive it is to FDI. A large market size is conducive to an increase in demand for products and services, allowing the achievement of economies of scale (Caves, 1971). Most of the studies in the literature suggest that the market size, proxies by real GDP or real GDP per capita, are found mostly to have a significant positive impact on FDI (Billington, 1999). Holland et al (2000) reviewed several studies for Eastern and central Europe, producing evidence of the importance of market size and growth potential as determinants of FDI. Tsai (1994) analyzed the decades of 1970 and 1980 and addressed the endogeneity problem between FDI and growth by developing a system of simultaneous equations. Also, FDI was alternately measured as a flow and as a stock. Market size turned out to be more important for FDI flows than growth. Campos and Kinoshita (2003) use panel data to analyze 25 transition economies between 1990 and 1998. They found FDI to be influenced by the low cost of labor and market size. Using panel data for 24 developing countries between the years of 1971 and 1985, Nair-Reichert and Weinhold (2001) found a positive relationship between FDI efficiency and a country's degree of trade openness. Interest rate is a measure of the cost of capital. A higher interest rate implies more costly investment and, therefore, the higher the interest rate, the more it is likely to defer FDI, and the relationship between FDI and the interest rate is expected to be negative. Love and Lage-Hidalgo (2000) and Erdal and Tatoğlu (2002), amongst others, found that an increase in the interest rate leads to a decrease in FDI.

\section{DATA AND ECONOMETRIC MODEL}

The study used time series data from 1988 to 2011. All the data were obtained from the International Financial Statistical year book. It is a known fact that every multinational corporation's decision to extend its activities abroad is, more often than not, motivated by a number of factors which always have cost reduction as the main defining character. Most firms will be influenced by what Dunning (1977) dubbed as "ownership," "location," and "internalization" (OLI) incentives that are available in the would-be host country. The scope of these factors is so widely sparse; however, that a significant chunk of it borders on research and development potential, human capital availability, market size, trade openness, exchange rate and infrastructure are some of the factors that influence FDI flows. This study intends to estimate the determinants of FDI flows to Ghana using time series data. The dependent variable is the FDI net inflows to Ghana. The study uses seven explanatory variables. In order to characterize the determinant of FDI flows to Ghana, we set up the following empirical model:

$\operatorname{lnFDI} t=\alpha_{\mathrm{t}}+\beta_{1} \operatorname{lnTO}_{\mathrm{t}}+\beta_{2} \operatorname{lnINFL}_{\mathrm{t}}+\beta 3 \operatorname{lnER} \mathrm{t}_{\mathrm{t}}+\beta_{4} \operatorname{lnPCGDP}_{\mathrm{t}}+\beta_{5} \operatorname{lnNR}_{\mathrm{t}}+\beta_{6} \operatorname{lnINFR}_{\mathrm{t}}$

$+\beta_{7} \operatorname{lnLIB}_{\mathrm{t}}+\varepsilon_{\mathrm{t}}$

where $\ln$ is the natural $\log , \mathrm{FDI}_{\mathrm{t}}$ is the dependent variable, the subscript $\mathrm{t}$ is the time period, TO is the trade openness, INFL is the rate of inflation, ER is the exchange rate, PCGDP is the per capita gross domestic product, 
NR is the natural resources, INFR is infrastructure, and Trade openness (TO) by a host country is considered as a major determinant of FDI, and has different effects on FDI. Studies have found a positive relationship between openness and FDI flows (Chakrabarti, 2001). Following Chakrabarti (2001), the trade volume is determined by the sum of exports and imports divided by nominal GDP as a proxy for trade openness and must be positively correlated with direct investment. The greater the degree of trade openness, the more it is directed towards external market that would be more open to foreign capital.

The rate of inflation (INFL) is used as a proxy for the level of economic stability. Considering that investors prefer to invest in more stable economies - that reflect a lesser degree of uncertainty - it is reasonable to expect that inflation would have a negative relation to direct investment.

Theory suggests that exchange rate (ER) volatility can either encourage or discourage FDI flows. The unstable foreign exchange market gives rise to an economic uncertainty, which is a barrier to FDI inflows. Most empirical, though, show that the exchange rate volatility hinders FDI inflows. Cushman (1985) and Froot and Stein (1991) stated that depreciation of a host country's currency expands inward FDI. This is because the depreciation of a host country's currency usually tends to reduce multinational firms' production costs. If FDI flows in the service sector; for example, have a marketing-seeking motive, then the depreciation of a host country's currency will promote FDI inflows. The real exchange rates used in our empirical analysis are bilateral real exchange rates defined by cedis/dollar real exchange rates divided by the source country's currency. Here it is expected that the sign of the estimated coefficient of real exchange rate is positive.

Previous studies show that the market size of a host country positively affects FDI and that GDP is used as a measure of market size. This study uses per capita GDP as a proxy for market size. The expected sign of the estimated coefficient of market size is positive. As Jenkins and Thomas (2002) observe, resource-seeking investors will locate subsidiaries abroad to secure a more stable or cheaper supply of inputs, generally raw materials and energy sources, but also factors of production. Morisset (2000) also shows that natural resource availability is very significant for the flow of FDI to developing countries. In this study, a total export is used as a proxy for natural resources (NR) since about 90 percent of Ghana's exports consist of natural resources. A positive sign is expected for the estimated coefficient.

Foreign investors prefer economies with a well-developed network of roads, airports, water supply, uninterrupted power supply, telephones, and internet access. Poor infrastructure increases the cost of doing business and reduces the rate of return on investment. All things being equal, production costs are typically lower in countries with well-developed infrastructures. Countries with good infrastructures are therefore expected to attract more FDI (Morisset, 2000). Infrastructure (INFR) is proxied by road network and is expected to be positively corrected with FDI. The economic and financial reforms have provided the necessary platform for investors to operate on the basis of operational flexibility and functional autonomy, thereby enhancing efficiency, productivity, and profitability. The reforms also have brought structural changes in both economic and financial sectors and succeeded in easing external constraints on its operation, introducing transparency in reporting procedures, restructuring and recapitalizing banks and companies, and enhancing the competitive element in the market (Aryeetey and Kanbur, 2005). Liberalization could stimulate greater competition in the economy through several channels. These include the new entry into the banking markets, the removal of interest rate control, and credit ceiling which should allow banks greater freedom to compete for customers and the privatization of government banks: Private sector banks might be expected to compete more aggressively against each other than banks owned by the public sector. For this purpose, liberalization policies (LIB) are incorporated into the model as a dummy variable. LIB is specified as to examine the effect of the structural changes in Ghana.

\section{RESULTS}

Regression analysis was carried out using relevant econometric techniques. Further multiple regression analysis was used to identify the major variables that have an impact on foreign direct investment. Relevant econometric tests, such as the coefficient of determination $\mathrm{R}^{2}$, standard error of coefficients, $\mathrm{T}$-statistics and F-ratio were carried out in order to assess the relative significance, desirability and reliability of model estimation parameters. 
Table 1 presents the descriptive statistics of the model.

Table 1: Descriptive Statistics

\begin{tabular}{|l|c|c|c|c|c|}
\hline \multicolumn{1}{|c|}{ Variables } & Mean & Median & Maximum & Minimum & Standard Deviation \\
\hline FDI & 3.70 & 9.80 & 2.95 & 2.0 & 7.29 \\
\hline TO & 2.70 & 1.90 & 1.19 & 1.35 & 2.79 \\
\hline INFL & 30.0 & 21.79 & 12.28 & 8.40 & 2.72 \\
\hline ER & 44.31 & 15.93 & 17.13 & 2.75 & 5.22 \\
\hline PCGDP & 53.46 & 39.14 & 17.40 & 12.59 & 2.42 \\
\hline NR & 2.58 & 1.90 & 7.98 & 1.35 & 2.42 \\
\hline INFR & 44.25 & 37.70 & 11.25 & 1.67 & 2.33 \\
\hline LIB & 0.688 & 1 & 32 & 0 & 0.471 \\
\hline OBSERVATION & 32 & 32 & 32 & 32 & 32 \\
\hline
\end{tabular}

The mean, standard deviation, minimum and maximum values for the independent and dependent variables suggest that several of them vary significantly. The unusually high maximum value for FDI flows was due to extremely high FDI flows in the 1990's and early 2000's, which marked a structural change in FDI flows in Ghana. Plausible explanations to this structural change in FDI flows in 1994 are the establishment of the Ghana investment promotion council to develop and promote investment in the country. As a matter of fact, this body promulgated laws to make the nation conducive to investment. Again, it was obvious that within this dispensation, the nation had reached an advanced stage in her exchange rate liberalization process. Further, the acquisition of the Ashanti Goldfields and a stake in Ghana Telecom by Telekom Malaysia partially accounted for this structural change in FDI flows into the country. Table 2 presents the correlation matrix of the variables.

Table 2: Correlation

\begin{tabular}{|l|c|c|c|c|c|c|c|}
\hline & TO & INFL & ER & PCGDP & NR & INFR & LIB \\
\hline TO & 1 & 0.432 & 0.095 & 0.093 & 0.097 & 0.098 & -0.086 \\
\hline INFL & 0.432 & 1 & -0.427 & 0.091 & -0.454 & -0.488 & -0.301 \\
\hline ER & 0.095 & 0.427 & 1 & 0.079 & 0.094 & 0.098 & -0.022 \\
\hline PCGDP & 0.093 & 0.091 & 0.079 & 1 & 0.089 & 0.090 & -0.263 \\
\hline NR & 0.097 & -0.454 & 0.094 & 0.089 & 1 & 0.096 & -0.021 \\
\hline INFR & 0.098 & 0.488 & 0.092 & 0.090 & 0.096 & 1 & 0.035 \\
\hline LIB & -0.086 & -0.301 & -0.022 & -0.263 & -0.021 & 0.035 & 1 \\
\hline
\end{tabular}

A look at the correlation matrix indicates that all relationships of the control variables with FDI were in the expected directions. INFR was moderately correlated with FDI, indicating that foreign investors (FIs) consider the operative INFR in choosing a destination for their investments.

In Table 3, we present the econometric results of the investment model that was estimated from panel data.

Table 3: Regression Results

\begin{tabular}{|l|c|c|}
\hline \multicolumn{1}{|c|}{ Variables } & Estimated Coefficients & T-Statistics \\
\hline Intercepts & $4.5008^{*}$ & $(2.356)$ \\
\hline TO & $0.04968^{*}$ & $(123)$ \\
\hline INFL & $1.0452^{*}$ & $(2.172)$ \\
\hline ER & $4.7480^{*}$ & $(2.109)$ \\
\hline PCGDP & $4.6802^{* *}$ & $(2.249)$ \\
\hline NR & $4.0201^{*}$ & $(1.818)$ \\
\hline INFR & $2.0704^{*}$ & $(2.4508)$ \\
\hline LIB & $4.6351^{* *}$ & \\
\hline$R^{2}$ & .947 & \\
\hline Adjusted ${ }^{2}$ & .932 & \\
\hline P-Value & .0001 & \\
\hline F-test & 61.737 & \\
\hline
\end{tabular}

Notes. $\quad$ Values in parentheses are t-values. FDI = foreign direct investment; TO = trade openness; INFL = inflation; ER = exchange rate; PCGDP = per capita GDP; NR= natural resources; INFR= infrastructure; LIB = dummy variable (liberalization).

*Significant at the .10 level. **Significant at the .05 level. ***Significant at the .01 level. 
The data used are annual, between the years of 1988 and 2011. The reason this time frame was chosen is because for the years prior to 1988 , some of the variables used in the model are not available. The study uses an ordinary least square (OLS) method to estimate the coefficients. The estimation by OLS with pooled data appears only as a reference, allowing us to check for the existence of multicollinearity in the model by way of a Variance Inflation Factor (VIF). The literature points out that there is indication of multicollinearity if the VIF is greater than 5 (Judge et al., 1982). Estimation by OLS may also give some sort of indication of an efficiency gain by estimating the model with panel data. The high-adjusted $\mathrm{R}^{2}$ values indicated that FDI inflows were adequately explained by the variations in the regressors. The coefficient for Trade openness (TO) was significant and had a positive impact on FDI as well, suggesting that an efficient environment that comes with more openness to trade is likely to attract foreign firms and that countries that embarked on trade liberalization were rewarded with more FDI. This conclusion is supported by Asiedu (2002) and Edwards (1990). The significance of the coefficient of trade openness confirmed that within the study period, foreign investment makes export-oriented investments in Ghana. This result suggests that trade openness is a catalyst factor for the improvement of Ghana attractiveness to FDI. Addison and Heshmati, (2003) used exports and imports as a percentage of GDP to analyze the impact of openness on FDI in 49 developing countries. Their findings indicate that FDI responds significantly to increased openness. The rate of inflation (INFL) is used as a proxy for macroeconomic stability. The coefficient for inflation variable is significant at the .05 level, with the expected sign. This finding implies that macroeconomic stability is an important determinant of foreign direct investment inflows to Ghana. This finding is supported by the results obtained by Addison and Heshmati (2003) and signifies the importance of a more focused macroeconomic policy environment that strengthens the economy and builds confidence for potential investors. The exchange rate coefficient is positive and significant at the .01 level. When the domestic currency depreciates, there can be negative or positive effects on FDI inflows. On the other hand, a real depreciation of the currency of the host country may reduce FDI inflows into the host country because a lower level of the exchange rate (measured in units of foreign currency per domestic currency) may be associated with lower expectations of future profitability in terms of the currency of the source country (Campa, 1993). On the other hand, a depreciation of the currency of the host country increases the relative wealth of foreign entrepreneurs and therefore may increase the attractiveness of the host country for FDI (Benassy et al., 2000; Cleeve, 2004). It is true that foreign exchange appreciates with FDI inflow and resource outflow. An increase in exchange rate leads to a decrease in FDI. The result is consistent with the finds of Cheng and Kwan (2002). Benassy et al. (2000) argue that a depreciation of the host currency makes, on the one hand, local assets and production cost comparatively cheaper and, on the hand, imports more expensive, therefore leading to higher inflows of FDI. However, a depreciated currency could also soften protectionism and hence reduce the incentive for foreign firms to enter the local market through producing locally as tariff jumping becomes less useful. We include per capita GDP as a proxy for market size in Ghana. The coefficient was positive and significant. It has been argued in the literature that the benefits accruing from FDI are conditional upon higher levels of absorptive capabilities (Borensztein et al. 1998) and are thus more likely to benefit from FDI liberalization. The result posits that per capita GDP is a vital determinant of FDI flows in Ghana. The result is consistent with the result obtained by Haile and Assefa (2005) who found per capita GDP to have a positive influence on FDI flows. The coefficient for natural resources (NR) was positive and significant suggesting that the increase in natural resources attracts more FDI flows. This result is consistent with the conclusion drawn by Asiedu (2006). Aseidu (2002, 2006), for example, reports that the availability of natural resources has a positive and significant effect on FDI inflows. Hailu (2010) conducts an empirical analysis of the demand side determinants of the inflow of FDI to African nations and concludes that natural resources, trade openness and infrastructure condition positively and significantly affect FDI inflows.

The infrastructure indicator (INFRA) is found to be negative and significant. This result may be explained by the poor transportation system which is detrimental to FDI inflow into the country. UNCTAD (2002) and Aseidu (2006) pointed out that one of the specific economic challenges and constrains identified by private investors in Ghana is the poor infrastructure facilities, particularly in the areas of telecommunications and transportation. Erdal and Tatoğlu (2002) report that the better the infrastructure of the host country, the more attractive it is to FDI. The study also finds a similar result for Malaysia. Similarly, the liberalization dummy is found to be a significant determinant of FDI, with the estimated coefficient possessing the expected sign in the regression model. This result suggests that liberalization of the Ghanaian economy has encouraged FDI inflows and it also supports the proposition that foreign investors are more likely to invest in countries that have opened up to the outside world. 


\section{CONCLUSUION}

The objective of this study was to shed light on the determinants of foreign direct investment (FDI) in Ghana. In order to undertake it, we performed an econometric model based on panel data analysis for the 1980-2011 periods. The study found trade openness, exchange rate, natural resources and infrastructure as the drivers of FDI in Ghana. Macroeconomic variables, such as inflation and per capita gross domestic products, were also found to be contributing to the determinants of FDI flows in Ghana. Finally, the contribution of this paper is that economic liberalization does really matter for FDI inflows in Ghana and policymakers' efforts in liberalizing the economic activities may necessarily translate into significant FDI inflows into the country.

\section{POLICY IMPLICATION AND RECOMMENDATION}

The economic benefits of FDI are real, but they do not accrue automatically. The magnitude of the benefits from FDI depends on the efforts of host countries to put in place the appropriate framework. Developing countries that are not doing well economically may use FDI as a supplement to scarce financial resources. By slacking financial restraint, FDI enables host countries to achieve the highest growth rates that generally originate from a faster pace of gross fixed capital formation. The eventual economic effect of FDI on economies with little other recourse to finance depends significantly on the policies pursued by host-country authorities (World Bank Group, 2007).

FDI-induced economic change may produce some adverse distributional and employment effects in the host country. The changes give rise to adjust costs and are resisted by the social groups that do not expect to be among the beneficiaries. Structural rigidities in the host economy aggravate such costs, not least where labor markets are too slow to provide new opportunities for individuals touched by restructuring. Overall, the costs are best alleviated when appropriate practices are pursued toward flexibility, coupled with macroeconomic stability and the implementation of adequate legal and regulatory frameworks.

Where economic and legal structures create a healthy environment for business, the entry of strong foreign corporate contenders tends to stimulate the host-country business sector, whether through competition, vertical linkages or demonstration effects. FDI tends to act as a catalyst for underlying strengths and weaknesses in the host economy, bringing to the fore both its advantages and its problems. Countries generally should not base their development strategies on the benefits of FDI. Inward FDI should be seen as a valuable supplement to local efforts rather than as a main source of growth. While FDI may contribute significantly to human capital formation, the transfer of state-of-the-art technologies, enterprise restructuring and increased competition, it is the host country authorities that must undertake basic efforts to raise education levels; invest in infrastructure, and improve the health of domestic business sectors.

Foreign investors are influenced by three broad groups of factors - the expected profitability of individual projects, the ease with which subsidiaries' operations in a given country can be integrated into the investor's global strategies, and the overall quality of the host country's enabling environment (World Bank, 2007). Sound hostcountry policies toward attracting FDI and benefiting from foreign corporate presence are largely equivalent to policies for mobilizing domestic resources for productive investment. An enabling domestic business environment is vital not only to mobilize domestic resources, but to attract and effectively use international investment.

Every aspect of host countries' economic and governance practices affects the investment climate. The overall goal for policymakers must therefore be to strive for the greatest possible macroeconomic stability and institutional predictability. Pursue sound macroeconomic policies that are geared to sustained high economic growth and employment, price stability and sustainable external accounts. Strengthen domestic financial systems, in order to make domestic financial resources available to supplement and complement foreign investment. A priority area is the development of capital markets and financial instruments to promote savings and provide long-term credit efficiently. This will help assuage funding constraints, in general, and allow local enterprise development to benefit those business opportunities arising from foreign corporate activities. This process will entail a progressive implementation of multilaterally agreed financial standards. 
The broader enabling environment for FDI is generally identical with best practices for creating a dynamic and competitive domestic business environment. FDI is unlikely unless investors have a reasonable understanding of the environment in which they will be operating. Moreover, a lack of transparency may lead to illicit and other unethical practices, which generally weaken the host country's business environment. In this context, the government should strengthen their efforts to consolidate the rule of law and good governance, including by stepping up efforts against corruption and enhancing policy and regulatory frameworks (e.g. as regards competition, financial reporting and intellectual property protection) to foster a dynamic and well-functioning business sector. Such policies will benefit the climate for FDI through their effect on transparency. By bringing a larger share of the informal economy into the open, they will also have important secondary effects on the countries' ability to attract investment.

The government should work toward increased openness to foreign trade so that the domestic enterprise sector can participate fully in the global economy. This approach should be undertaken jointly with efforts to increase business sector competition. A combined approach would allow a greater domestic and international openness to business, which works well with safeguards against the negative effects of a rise in concentration. Moreover, the successful elimination of global and regional trade barriers makes participating countries more attractive for FDI, owing to the concomitant expansion of the "relevant" market.

To reap the maximum benefits from corporate presence in a national economy, domestic competences, technologies and infrastructure need to be sufficiently well developed to allow nationals to take full advantage of the spillovers that foreign-owned enterprises generate. Host country authorities should therefore - with due regard to the balance between costs and expected benefits, and the state of development of the domestic economy - undertake measures to put in place relevant physical and technological infrastructure. The presence of such infrastructure is instrumental in attracting MNEs, in allowing national enterprises to integrate the technological spin-offs from foreign-owned enterprises in their production processes, and in facilitating their diffusion through the host economy. While host-country authorities should bear the brunt of the policy adjustments needed to reap the benefits of FDI for development, the home countries of MNEs - and the developed world, more generally - should review the ways in which their national policies affect developing countries. Thus, the benefits of FDI that flow from increased international trade integration and diffusion of technology, as mentioned, are influenced significantly by the policies of developed countries.

Further, trade liberalization would contribute substantially to the worldwide economic development, benefiting both developed and developing countries. In the FDI context, the trade policies of developed (home) countries gain a further dimension insofar as an important share of FDI is contingent upon subsequent trade between related enterprises. Trade barriers and subsidies aimed at limiting imports into developed countries currently impose costs on developing countries (the magnitude of which arguably exceeds aid flows). The authorities in developed countries could enhance developing countries' ability to attract foreign investment by working to reduce and eventually eliminate these barriers and subsidies.

Home-country governments need to assess the effects that their technology policies may have on the transfer of technologies to the host economy. Authorities can contribute to a positive outcome by encouraging MNEs to consider the technological needs of host countries.

\section{AUTHOR INFORMATION}

George Owusu-Antwi is currently a Visiting lecturer at the Ghana Institute of Management and Public Administration, Ghana. As an academician, Dr. Owusu-Antwi has taught several courses in finance at the Ghana Institute of Management and Public Administration as well as the Ghana Technology University College. His research and teaching interest is in corporate finance, investment, international finance and banking. He has published into International Business and Economic Research Journal. Dr. Owusu-Antwi has several years experience in banking and consulting. Dr. Owusu-Antwi is a Certified Mutual Fund Accountant. E-mail: Georgegowu@yahoo.com (Corresponding author) 
James Antwi is a lecturer at the Ghana Institute of Management and Public Administration (GIMPA) in Ghana and a Doctoral student at the SMC University. The author has over 16 years experience in information technology, project management and finance. He is a PMP certified and holds three masters' degrees in the field of systems science, business administration and financial economics. His research interest includes information systems and financial economics. E-mail: antwijames@yahoo.com

Peter Kwame Poku is a lecturer at the Ghana Institute of Management and Public Administration (GIMPA), Ghana. The author has several years in strategic management and teaches strategic management and business policy at GIMPA. His area of research interest includes small medium enterprises, business strategies and policy administration. E-mail: pkpoku@yahoo.com

\section{REFERENCES}

1. Addison, T. \& Heshmati, A. (2003). The new global determinants of FDI flows to developing countries. World Institute for Development Economics Research WIDER, Discussion Paper. No. 2003/45.

2. African Development Fund (2012). Republic of Ghana country strategy paper 2012-2016. Country Operations department-west 1 region

3. Aseidu, E. (2002). On the determinants of foreign direct investment to developing countries: Is Africa different? World Development 30:107-19.

4. Aseidu, E. (2006). Foreign direct investment in Africa: The role of natural resources, market size, government policy, institutions and political instability. The World Economy 29(1), 63-77.

5. Aryeetey, E., \& Kanbur, R. (2005). Ghana's economy at half century: An overview of stability, growth and poverty. Legon, Ghana: University of Ghana, Institute of Statistical, Social \& Economic Research.

6. Benassy, A., Larche-Revil, A. \& Fontague, L. (2000). MENA countries in the competition for FDI designing an exchange rate strategy. International Seminar GDR-EMMA, commissasriat du Plan, Paris.

7. Billington, N. (1999). The location of foreign direct investment: An empirical analysis. Applied Economics 31 (1) 65-78.

8. Blonigen, B. A. (2005) A review of the empirical literature on FDI determinants, Atlantic Economic Journal, 33(December), 383-403.

9. Borensztein, E., Gregorio, J. \& LEE, J. W. (1998) How does foreign direct investment affect economic growth? Journal of International Economics 45.

10. Buckley, P. \& Casson, M. (19976) The future of the multinational enterprise.London, Mac Millan.

11. Buckley, P. \& Casson, M. (1981) The optimal timing of a foreign direct investment. Economic Journal, (91).

12. Campa, J. (1993). Entry by foreign firms in the US under exchange rate uncertainty. Review of Economics and Statistics, 75 (4) 614-22.

13. Campos, N. F. \& Kinoshita, Y. (2003). Why does FDI go where it goes? New evidence from the transition economies. IMF Working Paper WP/03/228. International Monetary Fund. Washington, DC.

14. Caves, R.E. (1971). International Corporations: The industrial economics of foreign direct Investment. Economica., 38. 1-27.

15. Chakrabarti, A. (2001) The Determinants of foreign direct Investment: Sensitivity analyses of crosscountry regressions, Kyklos, 54(1), 89-113.

16. Cheng, L. K. \& Kwan, Y. K. (2002). What are the determinants of the location of foreign direct investment? The Chinese experience. Journal of International Economics. 51 (2). 379- 400.

17. Cleeve, E. (2004). How effectiveness are fiscal incentives to attract FDI to sun-Saharan Africa. Paper Presented at the IAABD $5^{\text {th }}$ International Conference Atlanta, April.

18. Cushman, D. O. (1985). Real exchange risk, expectations, and the level of direct investment. Review of Economics and Statistics 67(2), 297-308.

19. Deichmann J. I., Eshghi A., Haughton, D. M., Sayek, S \& Teebagy N. C. (2003). Foreign direct investment in the Eurasian Transition States. Eastern European Economics 41(1), 5-34.

20. Dunning, J. H. (1988). Explaining international production. London: Unwin Hyman.

21. Dunning, J. H. (1977). Trade, location of economic activity and the MNE: A search for an eclectic approach. In B. Ohlin, P.O. Hesselborn and P.M Wijkman (eds.), The International Allocation of Economic Activity, London: Macmillian, 395-418. 
22. Edwards, S. (1990). Capital flows, foreign direct investment, and debt-equity swaps in developing countries. NBER Working Paper 3497.

23. Erdal, F. \& Tatoğlu, E. (2002). Locational determinants of foreign direct investment in an Emerging market economy: Evidence from Turkey. Multinational Business Review 10 (1)

24. Froot, K.A \& Stein, J. C. (1991). Exchange rates and foreign direct investment: An imperfect capital markets approach. Quarterly Journal of Economics. 105. 1191-1218.

25. GabriBaldi, P., Mora, N., Sahay, R. \& ZettelMeyer, J. (2001). What moves capital to transition Economies. IMF Staff Papers, vol 48, Special Issue, International Monetary Fund.

26. Haile, G. \& Assefa, H. (2005). Determinants of foreign direct investment in Ethiopia: A time-Series analysis, paper presented at the $4^{\text {th }}$ International Conference on the Ethiopian Economy, Ethiopia. June.

27. Hailu, Z. A. (2010). Demand side factors affecting the inflow of foreign direct investment to African countries: Does capital market matter? International Journal of Business and Management 5(5), 104-116.

28. Holland, D.; Sass, M.; Benacek, V. \& Gronicki, M. (2000). The determinants and impact of FDI in Central and Eastern Europe: A comparison of survey and econometric evidence. Transnacional Corporations, 9 (3).

29. Hymer, S (1976). The International operations of national firms: A study of direct foreign investment. PhD Dissertation, MIT (publicada por MIT Press).

30. Jenkins, C. \& Thomas, L. (2002). Foreign direct investment in South Africa: Determinants, characteristics and implications for economic growth and poverty alleviation. Center for the Study of African Economics. University of Oxford.

31. Judge, G., Hill, C., Griffiths, W., Lee, T. \& Lütkepohl, H. (1982). Introduction to the Theory and Practice of Econometrics. New York: Wiley.

32. Kindlegerger,C.P. (1969). American Business Abroad: Six lectures on direct investment, New Heaven: Yale University Press.

33. Klein, M. \& Roengren, E. (1994). The real exchange rate and foreign direct investment in the United States: Relative wealth vs. relative wages effects. Journal of International Economics. 373-389.

34. Kosteletou, N, \& Panagiotis, L. (2000). Foreign direct investment and real exchange interlinkages, Open Economies Review 11:135-48

35. Love, J.H. \& Lage-Hidalgo, F. (200). Analyzing the determinants of US direct investment in Mexico. Applied Economics, 32 (10). 1259-1272.

36. Loree, D. W., \& e Guisinger, S. E. (1995). Policy and non-policy determinants of U. S. Equity Foreign Direct Investment. Journal of International Business Studies, 26, (2): 281-299.

37. Morrisset, P. (2000). Foreign direct investment to Africa: Policies also matter. Transnational Corporation 9, 107-125.

38. Nair-Reicheit, U. \& Weinhold, D. (2001). Causality tests for cross-country panels: New look at FDI and economic growth in developing countries. Oxford Bulletin of Economics and Statistics, 63(2). 151-171.

39. Ohlin, B. (1971). Comercio Interregional e Internacional. Oikos, Barcelona, 1971 (orig.1933).

40. Tsai, P. (1994). Determinants of Foreign direct investment and its impact on economic growth. Journal of Economic Development, $l 19$ (1).

41. Tsikata, G, Asante, Y \& Gyasi, K. (2000). Determinants of Foreign Direct Investment in Ghana, Overseas Development Institute.

42. Stevens, G. (1997). Exchange rate and foreign direct investment: A note. Journal of Policy Modelling.

43. UNCTAD (2007). World Investment Report. International Investment Instruments: A compendium, United Nations publication, United Nations, New York and Geneva.

44. UNCTAD. (1996, 1997, 1998, 2001, 2002, 2003). World Investment Reports, New York and Geneva: United Nations.

45. Vernon, R. (1966). International investment and international trade in the product cycle. Quarterly Journal of Economics, (80).

46. World Bank (2007). African Economic Outlook. 2005/2006. $5^{\text {th }}$ edition, The African Development Bank and The OECD Development Centre. New York.

47. Wheeler, D. \& Mody, A. (1992). International investment location decisions: The case for U.S. firms. Journal of International Economics (80) 190-207.

48. World Bank Group (2007). Snapshot Africa-Ghana. Benchmarking FDI competitiveness Multilateral Investment Guarantee Agency. World Bank, Washington DC. 
NOTES 